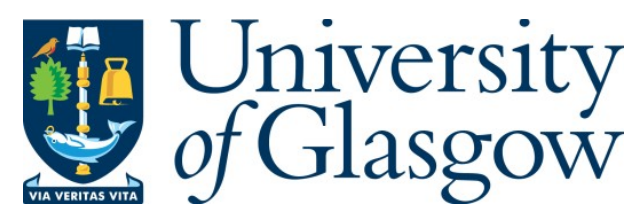

Arnold, P. L., Farnaby, J. H., Gardiner, M. G., and Love, J. B. (2015) Uranium(III) coordination chemistry and oxidation in a flexible small-cavity macrocycle.

Organometallics, 34(11), pp. 2114-2117.

There may be differences between this version and the published version. You are advised to consult the publisher's version if you wish to cite from it.

http://eprints.gla.ac.uk/135230/

Deposited on: 25 January 2017

Enlighten - Research publications by members of the University of Glasgow http://eprints.gla.ac.uk 


\title{
Uranium(III) Coordination Chemistry and Oxidation in a Flexible Small-cavity Macrocycle
}

\author{
Polly L. Arnold, ${ }^{* \dagger}$ Joy H. Farnaby, ${ }^{\dagger \#}$ Michael G. Gardiner ${ }^{\S}$ and Jason B. Love ${ }^{\dagger}$ \\ † EaStCHEM School of Chemistry, University of Edinburgh, The King's Buildings, Edinburgh EH9 3FJ, U. K. \# Current \\ address: Department of Chemistry, Imperial College London, South Kensington Campus, London, SW7 2AZ, UK. § School \\ of Physical Sciences (Chemistry), University of Tasmania, Private Bag 75, Hobart, Tasmania 7001, Australia.
}

KEYWORDS uranium, cation, oxidation, borohydride, macrocycle, pyrrolide, $N$-ligands, arene.

Supporting Information Placeholder

\begin{abstract}
The U(III) complexes of the conformationally flexible, small-cavity macrocycle transcalix[2]benzene[2]pyrrolide $(\mathrm{L})^{2-}$ [U(L)X] $(\mathrm{X}=(\mathrm{O}-2,6-$ $\left.\left.{ }^{t} \mathrm{Bu}_{2} \mathrm{C}_{6} \mathrm{H}_{3}\right), \mathrm{N}\left(\mathrm{SiMe}_{3}\right)_{2}\right)$ have been synthesized from $\left[\mathrm{U}(\mathrm{L}) \mathrm{BH}_{4}\right]$ and structurally characterized. These complexes show binding of the U(III) center in the bis(arene) pocket of the macrocycle, which flexes to accommodate the increase in steric bulk of $\mathrm{X}$, resulting in long $\mathrm{U}-\mathrm{X}$ bonds to the ancillary ligands. Oxidation to the cationic $\mathrm{U}(\mathrm{IV})$ complex $[\mathrm{U}(\mathrm{L}) \mathrm{X}]\left[\mathrm{B}\left(\mathrm{C}_{6} \mathrm{~F}_{5}\right)_{4}\right](\mathrm{X}=$ $\mathrm{BH}_{4}$ ) results in ligand rearrangement to bind the smaller, harder cation in the bis(pyrrolide) pocket, in a conformation that has not been previously observed for $(\mathrm{L})^{2-}$, with $\mathrm{X}$ located between the two ligand arene rings.
\end{abstract}

Organometallic actinide chemistry has revealed unusual new structures and reactivities, but many were and remain unpredictable or inexplicable because our fundamental understanding of this area of the periodic table is still so poor. The use of bulky monoanionic ligands has contributed significantly to defining the parameters that control the activation of small molecules by highly reducing U(III) centres. ${ }^{1}$ An alternative and very successful strategy has been the use of a single trianionic ligand framework to stabilize and coordinatively saturate the U(III) center while leaving a reactive pocket at the metal, with which to bind small molecules. $^{2}$

To further control the coordination environment around these reducing metal centers, we recently identified the dianionic macrocycle trans-calix[2]benzene[2]pyrrolide $(\mathrm{L})^{2-}$, Chart 1 , as a potential supporting ligand for low oxidation state actinide ions; ${ }^{1 \mathrm{a}, 3}$ it has previously been reported as a capable ligand for $\mathrm{Sm}(\mathrm{III}){ }^{4}$

Despite the small cavity size of this ligand, we demonstrated that $(\mathrm{L})^{2-}$ has sufficient flexibility to enable the stabilization either one or two $\mathrm{U}^{\mathrm{III}}$ cations, as
[UI(THF)(L)] and $\left[\mathrm{U}_{2} \mathrm{I}_{4}(\mathrm{~L})\right]$ respectively. ${ }^{3}$ The latter complex makes use of stabilizing, $\pi$-symmetry bonding interactions ${ }^{5}$ between the individual U(III) centers and either the two arenes (A, Chart 1) or the two pyrrolide (B, Chart 1) $6 \pi$-electron centers in the dinucleating macrocycle, and is an extremely rare example of a complex with two different U(III) coordination environments in the same compound. The degree of covalency in U-L bonding in both $[\mathrm{U}(\mathrm{L}) \mathrm{I}]$ and $\left[\mathrm{U}_{2} \mathrm{I}_{4}(\mathrm{~L})\right]$ was calculated, it was found that there was more covalent character to the U-pyrrolide bonding than to the U-arene bonding.
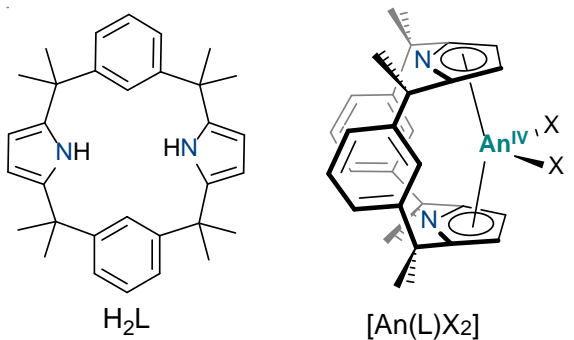

$\left[\mathrm{An}(\mathrm{L}) \mathrm{X}_{2}\right]$ $\mathrm{An}=\mathrm{Th}, \mathrm{X}=\mathrm{Cl} ; \mathrm{U}, \mathrm{X}=\mathrm{I}$

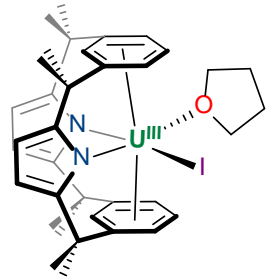

$[\mathrm{U}(\mathrm{L}) \mathrm{I}(\mathrm{THF})]$

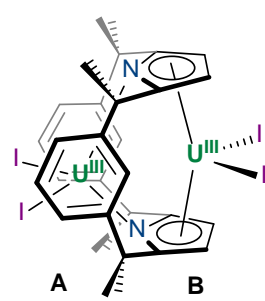

$\left[\mathrm{U}_{2} \mathrm{I}_{4}(\mathrm{~L})\right]$
Chart $1 \mathrm{H}_{2} \mathrm{~L}$ and low-oxidation state actinide complexes of trans-calix[2]benzene[2]pyrrolide $(\mathrm{L})^{2}$ including the dinuclear $\mathbf{U}(\mathrm{III})$ complex $\left[\mathrm{U}_{2} \mathbf{I}_{4}(\mathrm{~L})\right]$ showing the two different macrocycle binding pockets, either the two arenes (A) or the two pyrrolide (B) $6 \pi$-electron centers

The Th(IV) and U(IV) complexes of $(\mathrm{L})^{2-}$, all bind the An center in the bis(pyrrolide) pocket, suggesting that the bis(arene) binding pocket is preferred for the softer $\mathrm{An}(\mathrm{III})$ and indeed the reduction of $\left[\mathrm{U}(\mathrm{L}) \mathrm{I}_{2}\right]$ to $[\mathrm{U}(\mathrm{L}) \mathrm{I}]$ results in ligand rearrangement to this conformation. 
However, the difficulty of synthesis of these complexes directly from $\mathrm{UI}_{3}$ led us to develop a new synthesis of $\left[\mathrm{U}\left(\mathrm{BH}_{4}\right)_{3}(\mathrm{THF})_{2}\right]$, which proved to be a highly effective precursor for the synthesis of U(III) complexes including $\left[\mathrm{U}(\mathrm{L}) \mathrm{BH}_{4}\right] \mathbf{1}^{6}$

Here, we describe the use of $\mathbf{1}$ as an excellent U(III) precursor for the synthesis of a series of $[\mathrm{U}(\mathrm{L}) \mathrm{X}]$ complexes with increasingly bulky $\mathrm{X}$ ligands, its oxidation to the analogous $[\mathrm{U}(\mathrm{L}) \mathrm{X}]^{+}$cation, and the preferences for the bis(arene) binding motif in $(\mathrm{L})^{2-}$ ligand binding.

Reactions between 1 and $\mathrm{KX}$ (X = ODtbp = O-2,6- ${ }^{t} \mathrm{Bu}_{2}-$ $\left.\mathrm{C}_{6} \mathrm{H}_{3} ; \mathrm{N}^{\prime \prime}=\mathrm{N}\left(\mathrm{SiMe}_{3}\right)_{2}\right)$ in THF at ambient temperature result in [U(L)ODtbp] 2 (55\%) and [U(L)N"] 3 (35\%) as analytically pure dark purple solids after workup (Scheme 1). Complexes 2 and 3 are stable in the solid state and in solution for extended periods of time at room temperature and in boiling toluene. The ${ }^{1} \mathrm{H}$ NMR spectra of $\mathbf{2}$ and $\mathbf{3}$ in $d_{6}$-benzene are consistent with contact-shifted $C_{2 v}$ symmetric macrocyclic environments and $\eta^{6}: \kappa^{1}: \eta^{6}: \kappa^{1}$ metal-ligand binding (see below), with the geminal methyl groups observed as two nonequivalent (chemically and magnetically), contactshifted singlets of equal intensity, and additional resonances for the ancillary ligands.

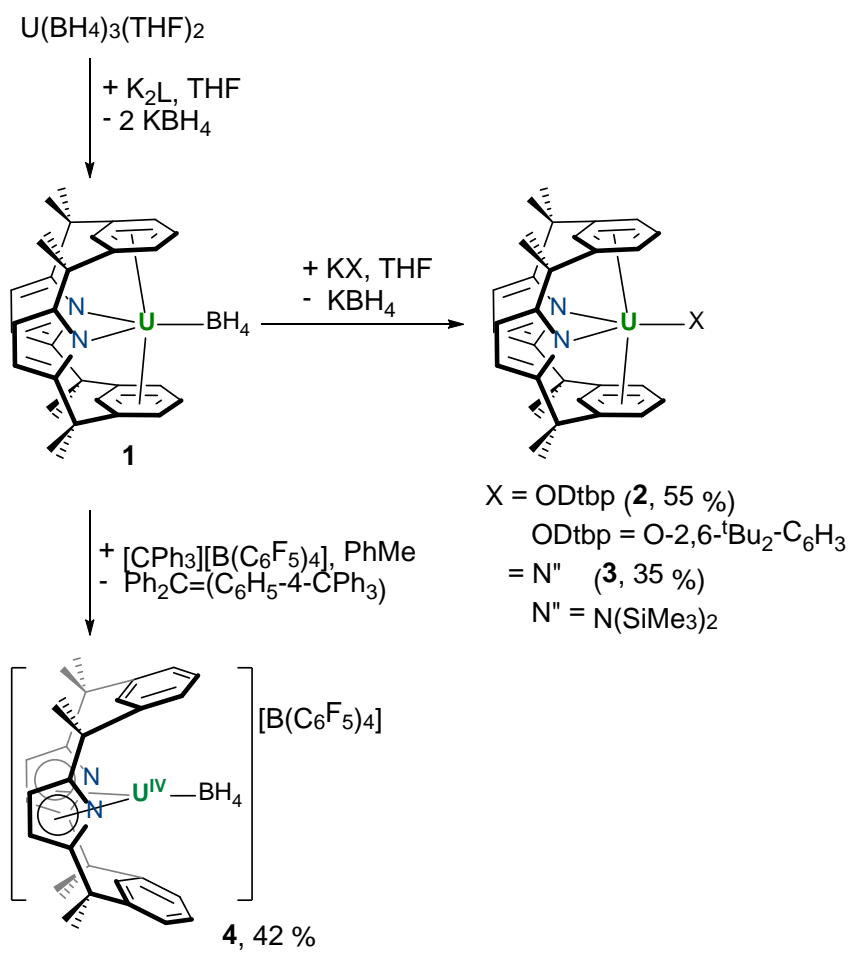

Scheme 1 Reactions of [ $\left.\mathrm{U}^{\mathrm{III}}(\mathrm{L}) \mathrm{BH}_{4}\right] 1$ to synthesize $\mathrm{U}^{\mathrm{III}}$ complexes [U(L)ODtbp] 2 and [U(L)N"] 3, and to form the cationic $\mathrm{U}^{\mathrm{IV}}$ complex $\left[\mathrm{U}(\mathrm{L}) \mathrm{BH}_{4}\right]\left[\mathrm{B}\left(\mathrm{C}_{6} \mathrm{~F}_{5}\right)_{4}\right] \mathbf{4}$

One driving force for these reactions is the elimination of THF-insoluble $\mathrm{KBH}_{4}$. The reaction between NaN" and $\mathbf{1}$ was found to be considerably slower, which we attribute to the less efficient elimination of $\mathrm{NaBH}_{4}$. It is also of note that the preferred synthetic route to U(III) aryloxides, i.e. protonolysis with HODtbp in a noncoordinating solvent, does not work. ${ }^{7}$ Complex 1 does not react with HODtbp in $d_{6}$-benzene even at elevated temperature.

The reaction of 1 with $\left[\mathrm{CPh}_{3}\right]\left[\mathrm{B}\left(\mathrm{C}_{6} \mathrm{~F}_{5}\right)_{4}\right]$ in toluene at ambient temperature resulted in a one electron oxidation to form the cationic $\mathrm{U}(\mathrm{IV})$ complex $\left[\mathrm{U}\left(\mathrm{BH}_{4}\right)(\mathrm{L})\right]\left[\mathrm{B}\left(\mathrm{C}_{6} \mathrm{~F}_{5}\right)_{4}\right] \mathbf{4}$ as a bright green solid in a 42 $\%$ yield after workup, with the formation of Gomberg's dimer $^{8} \quad$ (Scheme 1). Reactions between $\mathbf{1}$ and $\left[\mathrm{HNR}_{3}\right]\left[\mathrm{BPh}_{4}\right](\mathrm{R}=\mathrm{H}, \mathrm{Et})$ in THF did not result in the formation of an isolable product. Complex $\mathbf{4}$ is sparingly soluble in hydrocarbon solvents and decomposes on addition of THF. The ${ }^{1} \mathrm{H}$ NMR spectra of 4 in $d_{6^{-}}$ benzene/fluorobenzene is consistent with a $C_{2 v}$ symmetric macrocyclic environment. The change in oxidation state and ligand binding mode to $\eta^{1}: \kappa^{5}: \eta^{1}: \kappa^{5}$ is evidenced by the aryl protons closest to the metal center no longer being observed (they are readily measured and integrated in the ligand conformation exhibited by $\mathbf{2}$ and 3 ). This is also the case in $\left[\mathrm{U}(\mathrm{L}) \mathrm{I}_{2}\right]$, and attributed to the spatial proximity of the protons to the $5 f^{2}$ ion. ${ }^{3}$ The $\left(\mathrm{BH}_{4}\right)^{1-}$ is observed as a broad singlet at $11 \mathrm{ppm}\left(W^{1} / 2=\right.$ $201 \mathrm{~Hz}$ ) in the ${ }^{1} \mathrm{H}$ NMR spectrum (confirmed by ${ }^{1} \mathrm{H}\left\{{ }^{11} \mathrm{~B}\right\}$ NMR) and at 105 ppm in the ${ }^{11} \mathrm{~B}\left\{{ }^{1} \mathrm{H}\right\}$ NMR spectrum. The resonances for the $\left[\mathrm{B}\left(\mathrm{C}_{6} \mathrm{~F}_{5}\right)_{4}\right]^{-}$counter-ion are observed at -17.9 by ${ }^{11} \mathrm{~B}$ NMR and at $-134.7,-161.8$ and $-166.9 \mathrm{ppm}$, in the expected ratio, by ${ }^{19} \mathrm{~F}$ NMR. The IR spectrum of $\mathbf{4}$ displays absorptions in the region of 2500-2000 $\mathrm{cm}^{-1}$ consistent with $(\eta-\mathrm{H})_{3} \mathrm{BH}$ binding: $v(\mathrm{~B}-$ $\left.\mathrm{H}_{\mu}\right) 2532$ and $v\left(\mathrm{~B}-\mathrm{H}_{\mathrm{t}}\right) 2205 \mathrm{~cm}^{-1}$ and a strong absorption assigned to the bridge deformation at $1086 \mathrm{~cm}^{-1}$. These data confirm a return to the more usual $(\eta-\mathrm{H})_{3} \mathrm{BH}$ binding to the smaller $\mathrm{U}(\mathrm{IV})$ cation, in contrast to the $(\eta$ $\mathrm{H})_{2} \mathrm{BH}_{2}$ binding in $\mathbf{1}$, where the order of the absorptions is reversed: i.e. $v\left(\mathrm{~B}-\mathrm{H}_{\mathrm{t}}\right) 2414$ and $2384 \mathrm{~cm}^{-1}$ and $v(\mathrm{~B}-$ $\left.\mathrm{H}_{\mu}\right) 2120 \mathrm{~cm}^{-1}$. ${ }^{6}$ Interestingly the reaction of $\mathbf{1}$ with the simpler, commonly-used oxidant $\mathrm{Ph}_{3} \mathrm{CCl}$ does not yield a single product. ${ }^{10}$

Single crystals suitable for X-ray diffraction were grown by vapor diffusion of hexane into saturated THF (2), toluene (3) or fluorobenzene (4) solutions at ambient temperature over $7(2,3)$ or $3(4)$ days at ambient temperature; the structures are shown in Fig. 1 and structural parameters in Table 1. The structural features of interest are the interplanar arene angle and the long $\mathrm{U}-\mathrm{X}$ distances. The bis(arene) $\eta^{6}: \kappa^{1}: \eta^{6}: \kappa^{1}$ binding mode of the ligand in $\mathbf{2}$ and $\mathbf{3}$ is the same as for $\mathbf{1}$ and the $\mathrm{U}^{\mathrm{III}}$ iodide [U(L)I], with similar $\mathrm{U}-\mathrm{N}_{\text {pyrrolide }}$ distances also found. ${ }^{3}$ The interplanar arene angle gives a measure of uraniumarene interaction; the increase in steric bulk of the $\mathrm{X}$ ligand from $\left(\mathrm{BH}_{4}\right)$ in $\mathbf{1}$ to (ODtbp) and ( $\left.\mathrm{N}^{\prime \prime}\right)$ is reflected in an increase in this angle from $14.32^{\circ}$ to $17.30^{\circ}$ in 2 and $19.47^{\circ}$ in 3 . Long $\mathrm{U}-\mathrm{X}$ distances to the ancillary 
ligands are found in these sterically crowded complexes 2 and 3. The U1-O1 distance of 2.242(2) $\AA$ in 2 and the U1-N3 distance 2.365(3) $\AA$ in 3 are longer than in the homoleptic $\left[\mathrm{UX}_{3}\right]$ complexes of the same ligands: $\mathrm{U}-\mathrm{O}$
2.149(4)-2.165(3) $\AA$ in $\left[\mathrm{U}(\mathrm{ODtbp})_{3}\right]^{7}$ and U-N 2.320(4) $\AA$ in [UN" ${ }_{3}{ }^{11}{ }^{11}$ It is the same mode as observed by us in the Sm(II) chemistry of this ligand. ${ }^{5}$
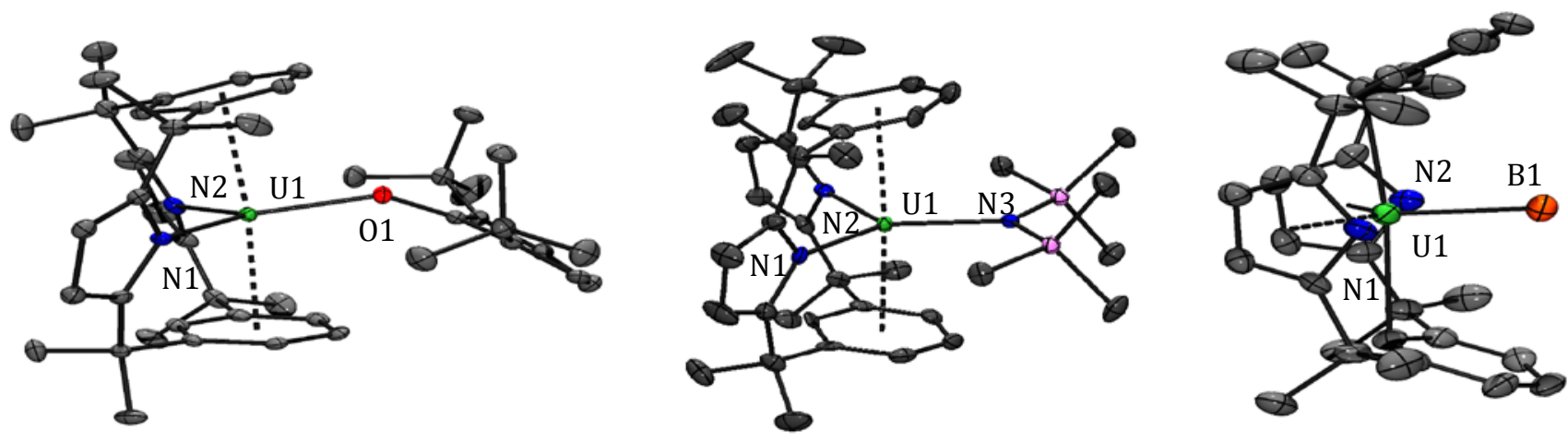

Figure 1. Solid-state structures of 2, 3 and the cation in $\mathbf{4}$ (displacement ellipsoids are drawn at 50 \% probability). For clarity $\left[\mathrm{B}\left(\mathrm{C}_{6} \mathrm{~F}_{5}\right)\right]^{-}$anion, lattice solvent and $\mathrm{H}$ atoms are omitted. cyclic cavity, with $\eta^{1}: \kappa^{5}: \eta^{1}: \kappa^{5}$ binding, and a dramatical-

Table 1 Selected bond distances $(\AA)$ and angles $\left({ }^{\circ}\right)$ for complexes 2, 3 and the cation in 4

\begin{tabular}{|c|c|c|c|}
\hline Complex & 2 & 3 & 4 \\
\hline \multicolumn{4}{|l|}{ Parameter } \\
\hline $\begin{array}{l}\mathrm{U} \text { oxidation } \\
\text { state; } \mathrm{r}_{\text {covalent, }} \\
\text { 6-coordinate }\end{array}$ & $+3 ; 1.165 \AA$ & $+3 ; 1.165 \AA$ & $+4 ; 1.103 \AA$ \\
\hline $\begin{array}{l}(\mathrm{L})^{2-} \text { binding } \\
\text { mode }\end{array}$ & $\eta^{6}: \kappa^{1}: \eta^{6}: \kappa^{1}$ & $\eta^{6}: \kappa^{1}: \eta^{6}: \kappa^{1}$ & $\eta^{1}: \kappa^{5}: \eta^{1}: \kappa^{5}$ \\
\hline $\begin{array}{l}\mathrm{U}-\mathrm{X}(\mathrm{X}=\mathrm{O} \\
\mathrm{N}, \mathrm{B})\end{array}$ & $2.2420(17)$ & $2.364(3)$ & $2.483(8)$ \\
\hline $\mathrm{U}-\mathrm{N}_{\mathrm{pyr}}$ & $\begin{array}{l}\text { 2.5375(19), } \\
2.4960(19)\end{array}$ & $\begin{array}{l}\text { 2.544(5), } \\
2.531(5)\end{array}$ & $\begin{array}{l}\text { 2.539(6), } \\
2.545(6)\end{array}$ \\
\hline $\mathrm{U}^{-\mathrm{Ct}_{\mathrm{ave}}}$ & 2.682 & 2.642 & 2.420 \\
\hline $\mathrm{N}_{\mathrm{pyr}}-\mathrm{U}-\mathrm{N}_{\mathrm{pyr}}$ & $116.94(6)$ & $114.63(16)$ & $178.97(18)$ \\
\hline Ct-U-Ct & 174.21 & 176.05 & 123.84 \\
\hline $\begin{array}{l}\text { Interplanar } \\
\text { arene angle }\end{array}$ & 17.30 & 19.47 & 50.40 \\
\hline
\end{tabular}

The molecular structure of 4 (Fig 1, Table 1) confirms the switch in binding mode from $\eta^{6}: \kappa^{1}: \eta^{6}: \kappa^{1}$ in 1 to $\eta^{1}: \kappa^{5}: \eta^{1}: \kappa^{5}$ to coordinate the $12 \%$ smaller U(IV) in a bis(pyrrolide) metallocene-type geometry, as we have found for all An(IV) ions so far. However, this is a new binding mode for $(\mathrm{L})^{2-}$, in contrast to the previously characterized $\left[\mathrm{An}(\mathrm{L}) \mathrm{X}_{2}\right]$ complexes (see Chart 1), which display $\kappa^{5}: \kappa^{5}$ metallocene-type binding between the two pyrrolide rings and an empty arene cavity. ${ }^{3}$ In 4 the smaller U(IV) cation is located deeper within the macroly increased interplanar arene angle of $50.40^{\circ}$ (compared to $14.32^{\circ}$ in $\left.\mathbf{1}\right)$. The $\kappa^{5}: \kappa^{5}$ pyrrolide metallocene-type binding is more compact in $\mathbf{4}$ than in $\left[\mathrm{U}(\mathrm{L}) \mathrm{I}_{2}\right]$, with shorter a U-Ct distance of $2.420 \AA$ and a smaller Ct-U$\mathrm{Ct}$ angle of $123.84^{\circ}$ ([U(L) $\left.\mathrm{I}_{2}\right]: 2.480 \AA$ and $163.26^{\circ}$ ). The $\left(\mathrm{BH}_{4}\right)^{1-}$ ligand remains within the arene cavity in $\mathbf{4}$ and the $\mathrm{U} 1 \cdots \mathrm{B} 1$ separation of $2.483(8) \AA$ is significantly contracted from that in 1 (2.927(7) $\AA$; $\left.(\eta-\mathrm{H})_{2} \mathrm{BH}_{2}\right)$ consistent with the smaller size of $\mathrm{U}(\mathrm{IV})$ and the $(\eta-\mathrm{H})_{3} \mathrm{BH}$ binding determined by FTIR. ${ }^{6}$ The ipso-carbons of the arene ring are very close to the U(IV) cation hence $\eta^{1}: \kappa^{5}: \eta^{1}: \kappa^{5}$, with U1 $\cdots \mathrm{C} 9$ and U1 $\cdots$ C29 separations of 2.745(7) $\AA$ and 2.735(7) $\AA$, longer than a U-C single bond (CSD average is $2.482 \AA$ ) but significantly shorter than the same parameters in $\left[\mathrm{UI}_{2}(\mathrm{~L})\right](\mathrm{U} 1 \cdots \mathrm{C} 9,3.045(5)$ $\AA$ and $\mathrm{U} 1 \cdots \mathrm{C} 29,3.022(5) \AA$ ). The binding mode in 4 is most similar to that seen in the singly aryl-metalated Sm(III) complex, $\left[\mathrm{Sm}(\mathrm{THF})\left(\mathrm{L}^{-\mathrm{H}}\right)\right]{ }^{4}$ However there is no evidence for ligand metalation in $\mathbf{4}$.

In conclusion, $\left[\mathrm{U}(\mathrm{L}) \mathrm{BH}_{4}\right]$ is a useful synthon for new $[\mathrm{U}(\mathrm{L}) \mathrm{X}]$ complexes $\left(\mathrm{X}=\left(\mathrm{O}-2,6-{ }^{\mathrm{t}} \mathrm{Bu}_{2} \mathrm{C}_{6} \mathrm{H}_{3}\right)\right.$, $\left.\mathrm{N}\left(\mathrm{SiMe}_{3}\right)_{2}\right)$. The U(III) complexes of $(\mathrm{L})^{2-}$ display a clear preference for bis(arene) binding of the U(III) center, in the formation of stable complexes with long U-X bonds. The arene cavity of macrocycle flexes to accommodate the increase in steric bulk of $\mathrm{X}$. [U( $\mathrm{L}) \mathrm{BH}_{4}$ ] can be cleanly oxidized to the cationic U(IV) complex $[\mathrm{U}(\mathrm{L}) \mathrm{X}]\left[\mathrm{B}\left(\mathrm{C}_{6} \mathrm{~F}_{5}\right)_{4}\right]\left(\mathrm{X}=\mathrm{BH}_{4}\right)$. We suggest that the change in oxidation state results in ligand rearrangement to bind the smaller, harder cation in the bis(pyrrolide) geometry preferred for An(IV), although in a conformation that has not been previously observed for $(\mathrm{L})^{2-}{ }^{2}$ 
Further work is in hand to identify the conformational changes that the ligand can adopt upon more extensive oxidation and ligand exchange reactions.

Selected characterizing data:

[U(L)ODtbp]: Dark purple microcrystalline solid, 56\%. ${ }^{1}$ H NMR (d $\boldsymbol{d}_{6}$-benzene): $\delta 15.3\left(\mathrm{br} \mathrm{s}, W^{1} / 2=18 \mathrm{~Hz}, 22 \mathrm{H}\right.$, pyrrolide $\mathrm{CH}$ and $\left.\mathrm{C}_{6} \mathrm{H}_{3}\left({ }^{t} \mathrm{Bu}\right)_{2} \mathrm{O}\right), 14.33$ (s, 2H, m$\left.\mathrm{C}_{6} \underline{\mathrm{H}}_{3}{ }^{(t} \mathrm{Bu}\right)_{2} \mathrm{O}$ ), 10.37 (s, $1 \mathrm{H} p-\mathrm{C}_{6} \underline{\mathrm{H}}_{3}\left({ }^{t} \mathrm{Bu}\right)_{2} \mathrm{O}$ ), 3.92 (s, $12 \mathrm{H}, \mathrm{CH}_{3}$ ), -2.68 (s, $12 \mathrm{H}, \underline{\mathrm{C}}_{3}$ ), -14.4 (br s, $W^{1} / 2=57$ $\left.\left.\mathrm{Hz}, 2 \mathrm{H}, \mathrm{C}_{6} \underline{\mathrm{H}}_{4}\right)\right),-19.3\left(\mathrm{v}\right.$ br s$, W^{1} / 2=123 \mathrm{~Hz}, 2 \mathrm{H}$, $\mathrm{C}_{6} \underline{\mathrm{H}}_{4}$ ), -26.0 (br s, $4 \mathrm{H}, m-\mathrm{C}_{6} \underline{\mathrm{H}}_{4}$ ), ppm. Analysis (\%) calc. for $\mathrm{C}_{46} \mathrm{H}_{57} \mathbf{N}_{2} \mathrm{OU}$ : C 61.94; H 6.44; $\mathrm{N} 3.14$, found C 61.98; H 6.53; N 3.13 .

[U(L)N"]: purple powder, 35\%. ${ }^{\mathbf{1}} \mathbf{H}$ NMR ( $\boldsymbol{d}_{\mathbf{6}}$-benzene): $\delta 15.05$ (s, 4H, pyrrolide $\mathrm{CH}$ ), 9.47 (s, $18 \mathrm{H}, \mathrm{SiMe}_{3}$ ), 5.20 (s, $12 \mathrm{H}, \mathrm{CH}_{3}$ ), -2.07 (s, $12 \mathrm{H}, \mathrm{CH}_{3}$ ), -12.7 (br s, $W^{\mathrm{T}} / 2=28$ $\mathrm{Hz}, 2 \mathrm{H}, \mathrm{C}_{6} \underline{\mathrm{H}}_{4}$ ), -16.3 (br s, $W^{1} / 2=63 \mathrm{~Hz}, 2 \mathrm{H}, \mathrm{C}_{6} \underline{\mathrm{H}}_{4}$ ), 26.8 (br s, $4 \mathrm{H}, m-\mathrm{C}_{6} \underline{\mathrm{H}}_{4}$ ), ppm. Analysis (\%) calc. for $\mathbf{C}_{38} \mathbf{H}_{54} \mathbf{N}_{3} \mathbf{S i}_{2} \mathbf{U}$ : C 53.88; H 6.43; N 4.96, found C 53.91; H 6.57; N 4.93.

[U(L)BH $\left.\mathbf{B}_{4}\right]\left[\mathbf{B}\left(\mathbf{C}_{6} \mathbf{F}_{5}\right)_{4}\right]$ 4: green powder, $42 \%$. ${ }^{\mathbf{1}} \mathbf{H}$ NMR ( $\boldsymbol{d}_{6}$-benzene/flurobenzene): $\delta 27.55\left(\mathrm{~s}, 12 \mathrm{H}, \mathrm{CH}_{3}\right), 11.1$ (br s, $4 \mathrm{H}, \mathrm{BH}_{4}, W^{1} / 2=201 \mathrm{~Hz}$ ), $-2.08(\mathrm{~s}, 4 \mathrm{H}$, pyrrolide $\mathrm{CH}),-5.29$ (s, $\left.12 \mathrm{H}, \mathrm{CH}_{3}\right),-20.53\left(\mathrm{~s}, 4 \mathrm{H}, p-\mathrm{C}_{6} \underline{\mathrm{H}}_{4}\right),-38.7$ (br s, $W^{1} / 2=40 \mathrm{~Hz}, 2 \mathrm{H}, m-\mathrm{C}_{6} \underline{\mathrm{H}}_{4}$ ) ppm. IR (nujol mull, $\left.\mathbf{B a F}_{2}\right): 2532(\mathrm{~m}) v\left(\mathrm{~B}-\mathrm{H}_{\mu}\right), 2205(\mathrm{w}) v\left(\mathrm{~B}-\mathrm{H}_{\mathrm{t}}\right), 1643(\mathrm{~m})$, 1514 (s), 1276 (m), 1209 (m), 1086 (s) (bridge deformation) $\mathrm{cm}^{-1}$. Analysis (\%) calc. for $\mathbf{C}_{56} \mathbf{H}_{40} \mathbf{B}_{2} \mathbf{F}_{20} \mathbf{N}_{\mathbf{2}} \mathbf{U}$ : C 48.72; H 2.92; N 2.03, found C 48.56; H 2.86; N 2.12.

\section{ASSOCIATED CONTENT}

Supporting Information. Experimental details, characterization data and full crystallographic data (X-ray structural CCDC codes 1036264-6). This material is available free of charge via the Internet at http://pubs.acs.org.

\section{AUTHOR INFORMATION}

\section{Corresponding Author}

*Polly.Arnold@ed.ac.uk

Notes

The authors declare no competing financial interest.

\section{ACKNOWLEDGMENT}

The authors acknowledge the University of Edinburgh and the EPSRC for funding.

\section{DEDICATION}

Dedicated to the late Professor Michael F. Lappert FRS.
(1) (a) Arnold, P. L.; McMullon, M. W.; Kühn, F. E.; Rieb, J. Angew. Chem., Int. Ed. 2014, DOI: 10.1002/anie.201404613. (b) Ephritikhine, M. Organometallics 2013, 32, 2464. (c) Arnold, P. L. Chem. Comm. 2011, 47, 9005. (d) Higgins, J. A.; Cloke, F. G. N.; Roe, S. M. Organometallics 2013, 32, 5244. (e) Mansell, S. M.; Farnaby, J. H.; Germeroth, A. I.; Arnold, P. L. Organometallics 2013, 32, 4214. (f) Arnold, P. L.; Mansell, S. M.; Maron, L.; McKay, D. Nat. Chem. 2012, 4, 668. (g) Cooper, O.; Camp, C.; Pecaut, J.; Kefalidis, C. E.; Maron, L.; Gambarelli, S.; Mazzanti, M. J. Am. Chem. Soc. 2014, 136, 6716. (h) Evans, W. J.; Mueller, T. J.; Ziller, J. W. Chem. Eur.J. 2010, 16, 964.

(2) (a) La Pierre, H. S.; Kameo, H.; Halter, D. P.; Heinemann, F. W.; Meyer, K. Angew. Chem. Int. Ed. 2014, 53, 7154. (b) Gardner, B. M.; Stewart, J. C.; Davis, A. L.; McMaster, J.; Lewis, W.; Blake, A. J.; Liddle, S. T. PNAS 2012, 109, 9265.

(3) Arnold, P. L.; Farnaby, J. H.; White, R. C.; Kaltsoyannis, N.; Gardiner, M. G.; Love, J. B. Chem. Sci. 2014, 5, 756.

(4) Ilango, S.; Vidjayacoumar, B.; Gambarotta, S. Dalton Trans. 2010, 39, 6853.

(5) Gardiner, M. G.; Frey, A. manuscript in preparation.

(6) Arnold, P. L.; Stevens, C. J.; Farnaby, J. H.; Gardiner, M. G.; Nichol, G. S.; Love, J. B. J. Am. Chem. Soc. 2014, 136, 10218.

(7) Mansell, S. M.; Kaltsoyannis, N.; Arnold, P. L. J. Am. Chem. Soc. 2011, 133, 9036.

(8) Lankamp, H.; Nauta, W. T.; MacLean, C. Tet. Lett. 1968, 9, 249.

(9) Marks, T. J.; Kolb, J. R. Chem. Rev. 1977, 77, 263.

(10) Arnold, P. L.; Turner, Z. R.; Kaltsoyannis, N.; Pelekanaki, P.; Bellabarba, R. M.; Tooze, R. P. Chem. Eur. J. 2010, 16, 9623.

(11) Stewart, J. L.; Andersen, R. A. Polyhedron 1998, 17, 953.

(12) Shannon, R. D. Acta Crystallogr., Sect. A: Found. Crystallogr. 1976, 32, 751.

\section{REFERENCES}


U(III) complexes of the conformationally flexible, small-cavity macrocycle transcalix[2]benzene[2]pyrrolide $(\mathrm{L})^{2-}[\mathrm{U}(\mathrm{L}) \mathrm{X}]\left(\mathrm{X}=\left(\mathrm{O}-2,6-{ }^{\mathrm{t}} \mathrm{Bu}_{2} \mathrm{C}_{6} \mathrm{H}_{3}\right), \mathrm{N}\left(\mathrm{SiMe}_{3}\right)_{2}\right)$ show $\mathrm{U}(\mathrm{III})$ binding in the bis(arene) pocket of the macrocycle, which flexes to accommodate the increase in steric bulk of X. Oxidation to the cationic $\mathrm{U}(\mathrm{IV})$ complex $[\mathrm{U}(\mathrm{L}) \mathrm{X}]\left[\mathrm{B}\left(\mathrm{C}_{6} \mathrm{~F}_{5}\right)_{4}\right]\left(\mathrm{X}=\mathrm{BH}_{4}\right)$ results in ligand rearrangement to bind the smaller, harder cation in bis(pyrrolide) pocket, but in a conformation that has not been previously observed for $(\mathrm{L})^{2-}$ with the $\mathrm{X}$ ligand located in between the two ligand arene rings.

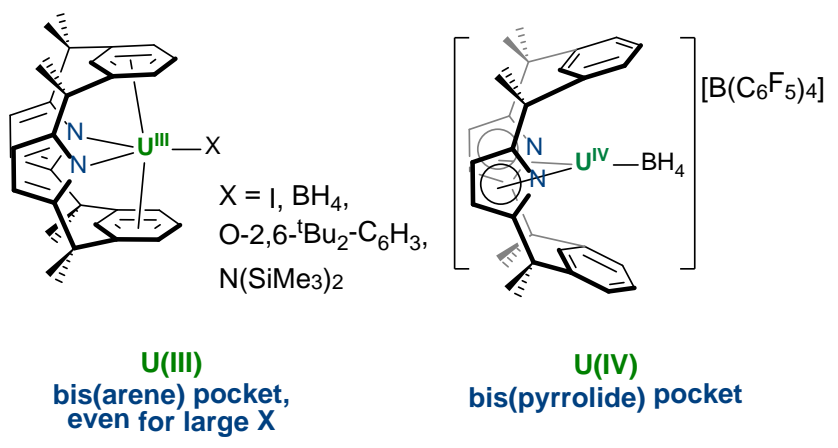

